\title{
On Translating Culture-Bound Expressions in Naguib Mahfouz's The Thief and the Dogs and strategies: A Comparative Study in Arabic-English Translation
}

\author{
Dr. Yousreya Ahmed Ali Alhamshary \\ Associate professor of Linguistics, Department of English \\ Faculty of Education, Damanhour University
}

\begin{abstract}
The translation of Naguib Mahfouz's work has been a reflective source of the Egyptian culture, heritage, and values of the society for the outside world from the time of its writing till now. Therefore, many of his works have been translated into English and other languages, including the present one The Thief and the Dogs" Allasu Walkalab”, the topic of this research. This comparative study aims to find out strategies, similarities, and differences in the English translation of an Arabic descriptive text in one of the greatest works, translated by Trevor Le Gassick and Mohamed Badawi. This research paper applies Mona Baker's (1992) theory to define the translation strategies used in the novel that serve the delivery of the cultural bound terms in the original text message. The corpus of the study consists of (159) cultural bound terms selected from the original text of the novel. Corpus are classified according to the types and context into historical, religious, ecological, psychological, and material cultural bound terms. Finally, a conclusion is drawn based on the assessment of the English translation; frequencies and percentages are calculated. It has been found that seven strategies are implemented but the most usable one is paraphrasing.
\end{abstract}

Keywords:

Cultural-bound Terms, Translation Strategies, Naguib Mahfouz, Baker's Taxonomy. 
في ترجمة ملامح الثقافة المصرية في رواية اللص والكلاب للروائي

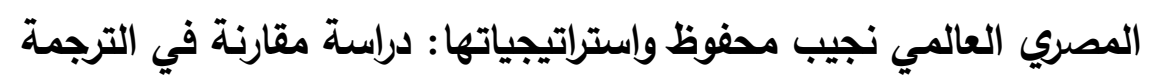
من العربية إلى الإنجليزية

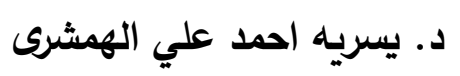

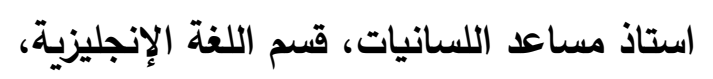

كلية التربية، جامعة دمنهور

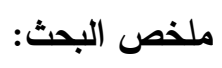

كانت ومازالت ترجمة أعمال الكاتب المصري الكبير نجيب محفوظ هي النموذج العاكس

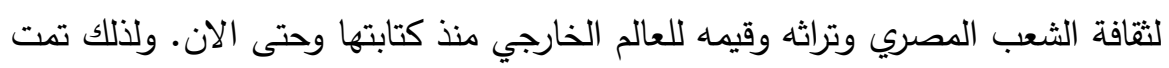

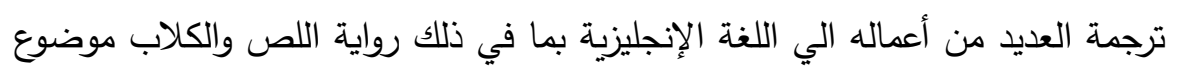

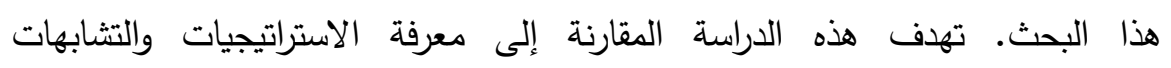

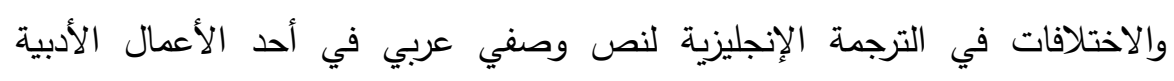

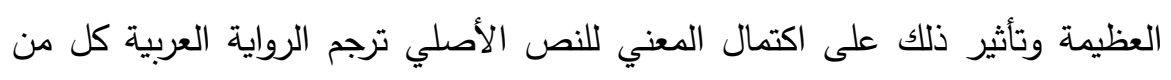

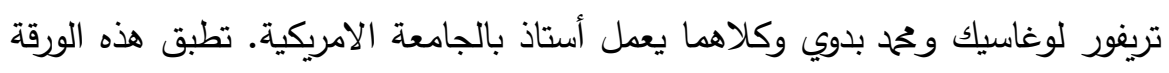

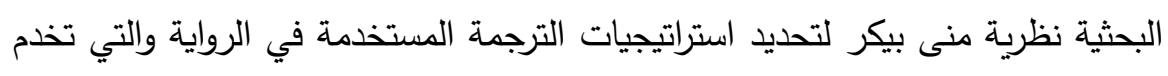

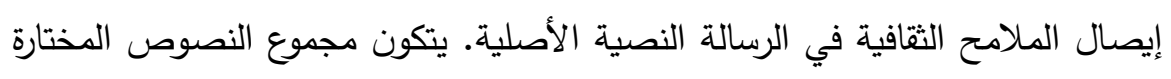

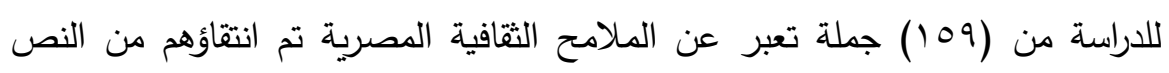
الأصلي للرواية. تصنف هذه الملامح حسب الأنواع والسياق إلى ملامح ثنافية تلثية تاريخية

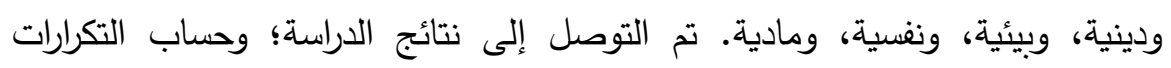

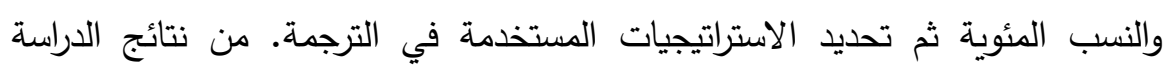
استخدام سبع استراتيجيات وأكثرها تكرارا إعادة الصياتة الصنات. كلمات مفتاحية:

الملامح الثقافية، استراتيجيات الترجمة، نجيب محفوظ ، تصنيف بيكر . 
On Translating Culture-Bound Expressions in Naguib Mahfouz's The Thief and the Dogs and strategies: A Comparative Study in Arabic-English Translation Dr. Yousreya Ahmed Ali Alhamshary

مجلة وادي النيل للاراسات والبحوث الإنسانية والاجتماعية والتربوية (مجلة علمية محكمة)

\section{Introduction}

Literary translation is of great importance for it plays a good role in shaping the world around us and leads to the appropriate understanding of life. Translated literary works allow more people to enjoy literature of other cultures. Reading translations of literary works provides insights into life in other cultures and other countries through the possible values, principles, and thoughts the writers reflect about their societies. Hence, translation of literature gets people closer from different locations, paves the way to get them understand each other's current generations and leads to appropriate communication (Muhaidat \& Neimneh, 2011; Mohamed, 2014). Without literary translation one cannot know about the accumulated wisdom and ancient knowledge of other cultures. As Bhabha (1994) points out that translation is the performative nature of cultural communication. Whereas Bassnett (1980, p. 138) looks at translated literary text as the type of genre providing such a rich field for exploration by both translation studies and cultural studies practitioners in which individual strategies employed by writers deliberately to construct images of other cultures for consumption by reader can be most clearly seen. She also refers to the importance of having comparative studies about translating literary text as it becomes a cultural capital across cultural boundaries. Another issue to be considered is that literary texts or works contain specific words and structures that scholars of translation and translators think that they are too difficult to translate compared to other text types. One of the challenges in translating a literary text is to keep the message behind it and the effect of the original text including cultural references (Haque, 2012). Liu (1991, p. 7) says: "The difficulty in translation just lies in the fact that both the content and the style are already existent in the original and as a result, you will have to do your best to reproduce them as they are in quite a different language.". Consequently, it is very difficult to keep balance between what needs to be translated correctly, and what must be understood depending mainly on word choice. The comparison of both texts in 
(ISSN : 2536 - 9555)

Arabic and English languages inevitably involves a theory of equivalence that caused heated arguments about the concept of its meaning and how it is handled in literary text in the past fifty years. The translated text usually clashes with the problem of the culture of text produced through linguistic relationships controlled by different mechanisms that are different from those of the listener or the reader, who may understand the text, but it is not inevitable to taste its aesthetic meaning. At the same time, equivalence remains an essential element in the practice, assessment, and study of translation (Baker, 1992; Kashgary 2011; Saule \& Aisulu, 2014; Abdul Wahab \& Ali, 2016). Culturespecific (bound) items (terms) are linguistic items that may pose problems for translators; because they are embodied in the ST and sometimes do not exist in the culture of the TL (Aixela 1996: p.57). Therefore, preserving the flavour of the original culture a set of translation strategies are used to handle them, while others try to guarantee issues such as naturalness, acceptability, and readability in the target culture (Newmark 1988, Baker 1992)

The present research tries to find out how cultural-specific terms of the Egyptian society, in one of the great sources for the Egyptian culture written by Nagub Mahfouz, are transferred by the translator and how far he is successful in expressing their meaning. Another focus of the research is to identify the strategies used in translation of these terms.

\section{Theoretical Background}

Translation has been used to transfer written or spoken source language (SL) texts to equivalent written or spoken target language (TL) texts. In general, the purpose of translation is to reproduce various kinds of texts-including religious, literary, scientific, and philosophical texts - in another language and thus making them available to wider readers. The history of any society starts from the folk which is an integral part of the identity and history of any society. The Egyptian folk is one of the richest sources for values and principles of the old Egyptian family life. Wishing to shed light on this type of written literary work and its 
On Translating Culture-Bound Expressions in Naguib Mahfouz's The Thief and the Dogs and strategies: A Comparative Study in Arabic-English Translation Dr. Yousreya Ahmed Ali Alhamshary

مجلة وادي النيل للار اسات والبحوث الإنسانية والاجتماعية والتربوية (مجلة علمية محكمة)

related social life, one of the greatest Egyptian writers focuses on this as to be the glass by which the world sees Egyptian values and principles. Naguib Mahfouz is considered one of the world's most renowned Arabic Egyptian novelists. Most of his work is concerned with his native country Egypt and covers a wide range of topics therein, from all classes of the society middle, lower, to the civilization's ancient history class life. He was deeply influenced by the 1919 Egyptian Revolution, which led him to adopt the nationalist ideals so present in much of his work. Naguib Mahfouz remains one of those exceptional Arab novelists whose works represent the social and political life of Egypt. He has successfully Arabicized Western elements while developing Eastern ones. His Nobel Prize, coupled with recent interest in the literature of the Arab world, may just provide the recognition that modern Arabic literature deserves and needs (Salti, 1990).

The story of The Thief and the Dogs is about the life of Said Mahran, a thief or revolutionary anarchist that had been recently released from jail and intent to have his vengeance on the people who put him there. 's world revolves around Nabawiyya, his former wife who betrayed him by marrying his friend 'Ilish and Sana', his daughter. Rauf Ilwan, who used the same revolutionist rhetoric, is a respected journalist and businessman, but the third enemy to him. Only Nur, a prostitute, and Tarzan, a café-owner, provide with any respite from his anger and the world at large which is closing in on him, yet in time even they cannot help him.

Translation, according to Nida and Taber (1982), is a process of "reproducing in the receptor language the closest natural equivalence of the source language message, first in terms of meaning and secondly in terms of style". Translation theorists assert that translation of a literary text is a difficult task, particularly the translation of a text written in the form of poetry (Nida, 1964; Newmark, 1988; Bassnett, 2002). When discussing the problems of correspondence in translation, "differences between cultures may cause more severe complications for the translator than do differences in language structure" (Nida, 1964, p. 
(ISSN : 2536 - 9555)

130). In the 1970s there was a growing realization that literary texts are constituted not of language but of culture, language being just a vehicle of culture. Lefevere (1994), one of the major translation scholars who linked translation with cultural studies, points out that in this way translation can be studied as one of the strategies cultures develop to deal with what lies outside their boundaries and to maintain their own character while doing so the kind of strategy that ultimately belongs to the realm of change and survival, not in dictionaries and grammars.

Hardwick (2004, p. 22) suggests that the act of translating words also "involves translating or transplanting into the receiving culture the cultural framework within which an ancient text is embedded". The act of translation involves wayward attempts at bridging two societies which are diverse linguistically and culturally. The hermeneutic context would determine the quantity and type of translations that might be undertaken, and the status of those translations would be greater or lesser according to the position of the receiving culture. So, a work could be fundamentally important in the source culture and could then be translated and have no impact at all in the receiving culture or, vice versa, a translation could alter the shape of the receiving literary system. Finding the appropriate cultural equivalents is not always easy for translators, that is why "translators should be bicultural, not bilingual" as stated by Bassnett and Lefevere (1998. p. 11). Translation activities should be regarded as having cultural significance. The acquisition of a set of norms for determining the suitability of that kind of behaviour and for maneuvering between all the factors which may constrain it is therefore a prerequisite for becoming a translator within a cultural environment. (Toury, 1995)

As Baker (2018) points out that cultural equivalence gives the reader a concept with which s/he can identify something familiar and appealing, and likely to have a similar impact on the target reader. Finding the appropriate cultural equivalents is not always easy and that translators should be bicultural, not bilingual (Al-Saidi, 2013). Catford (1965) makes a distinction between linguistic and cultural untranslatability. Focusing on the question 
On Translating Culture-Bound Expressions in Naguib Mahfouz's The Thief and the Dogs and strategies: A Comparative Study in Arabic-English Translation Dr. Yousreya Ahmed Ali Alhamshary

مجلة وادي التيل للاراسات والبحوث الإنساتية والاجتماعية والتربوية (مجلة علمية محكمة)

of what is untranslatable; he argues that linguistic untranslatability occurs when there is no lexical or syntactical equivalent in the TL. He saw cultural untranslatability as more complex and loosely formulated: something is culturally untranslatable when there is no equivalent situational feature in the source language.

According to Munday (2012) scholars regard literary texts different from other texts in terms of words and structures. However, others consider literary texts as a production of social cultures. Consequently, a literary work is a matter of social and cultural aspects. Furthermore, he considers literature as a subsystem of a society or a culture. Hence, literary translation is also the translation which is related to the cultural and social issues and matters. Baker's (1992) taxonomy of equivalence comprises the Traditional approach which is word and structure-based and the novel approach which is culture based one. Thus, it can be used for any type of texts as a translation quality assessment.

The present research compares a target text to its source text to evaluate the degree of equivalence in translating the cultural and narrative language of Naguib Mahfouz if the reader's response is used to evaluate the delivered message is correct or not as the ST did with the original readers; surely the text itself is not a sufficient criterion. As a certain meaning or message is produced through the interaction of the ST and the original reader's schemata, the role of translator is expected to reproduce a high degree of equivalent meaning or message reproduction from the interaction of the TT and its readers. Thus, the translated text should provide textual guidelines for each stage of interaction in text processing with the reader depending on his knowledge or background about the original cultural or social context. The reproduction of the same or even almost readers' response in the translated text is considered as criteria for measuring the quality of equivalence in the translated text.

Translation is important in general as it forms a very big part of individuals' personality and control or guide their behavior. For Bassnett (2002), translation includes the rendering of a 
(ISSN : 2536 - 9555)

message in the SL into the TL to the reader to ensure that the surface meaning of the two languages will be approximately similar and at the same time the structures of the SL will be preserved as closely as possible but not so closely that the TL structures might be seriously distorted. Consequently, Baker (1992, p. 5) formulates four kinds of equivalence, the first equivalence is at word level and above word level, when translating from one language into another, which means that the translator should pay attention to several factors when considering a single word, such as number, gender, and tense (Pym, 1992, p. 11-12). Second, grammatical equivalence refers to the diversity of grammatical categories when indicating the variety of grammatical classes (number, tense and aspects, voice, person, and gender) across language. Third, textual equivalence refers to the equivalence between a SL text and a TL text in terms of information, consistency, and cohesion. Here, three main factors guide the translator's decision, namely, the text type, the purpose of the translation, and the target audience. Fourth, pragmatic equivalence refers to imprimaturs and strategies of avoidance during the translation process; Implicature signifies what is suggested in an utterance (Blackburn, 1996, p. 188-89). Moreover, Baker (2018) illustrates the non-equivalents to which a translator comes across while translating for both languages that have their distinguished specific culture as: a) Culture specific concepts; b) A SL word that is semantically complex; c) A TL lacks a specific term or (hyponym); d) Differences in expressive meaning; e) Differences in frequency and /or purpose of using specific forms; f) A SL concept that is not lexicalized in TL;g) A S/T languages that make different distinction in meaning; h) A TL that lacks a superordinate; i) Differences in physical or interpersonal perspective; j) Differences in form; $k$ ) The use of loan words in the source text. All these types of non-equivalents can distort the meaning and only bicultural translator can solve them and appropriately send the reader in a mid-point where he cannot lose any of the meaning. 
On Translating Culture-Bound Expressions in Naguib Mahfouz's The Thief and the Dogs and strategies: A Comparative Study in Arabic-English Translation Dr. Yousreya Ahmed Ali Alhamshary

مجلة وادي النيل للاراسات والبحوث الإنسانية والاجتماعية والتربوية (مجلة علمية محكمة)

The role of the translator is to re-establish the author's purpose in another culture in such a way that facilitates clear comprehension for the target culture reader. However, a lot of translators find it difficult to translate cultural expressions for the cultural context is always vague as it may include religious beliefs, social habits, customs and traditions or social situations, moral values, a type of cloth or a lifestyle, kind of food or even economical principle, political ideology...that are specific to the culture in question. To render feelings in a descriptive scene to reflect on different emotions, humor, or sadness from one culture to another are main concerns of the translator. Henceforth, when translating cultures linguistic element should be related to the cultural context they belong to. Thus, translators should be aware of the contrast in the entire range of culture represented by the two languages. Meaning that, language is considered as a part of culture and the society's identity.

Sutopo (2001, p. 1) states that "translation consists of reproducing in the receptor language in the closest natural equivalent of the source language message, first in terms of meaning and secondly in terms of style". To Paz (1971, p. 9) every text is unique and at the same time can be a translation of another text. Consequently, no text is entirely original. However, all texts are original because every translation is distinctive. Every translation mostly, is an invention and as such it constitutes a unique text. To theorists like Newmark (1988), dynamic equivalence is viewed as a translation code where a translator looks for rendering the meaning of the original in such a way that the TL readers will enjoy the text as is done usually by the ST readers. He categorizes cultural bound terms to five categories namely, ecology, material culture (artefacts), social culture -work and leisure, organizations, customs, activities, procedures, concepts (political and administrative, religious, artistic) and gestures and habits. The reproduction of text to the reader or listener of the literary work (novel of The Thief and the Dogs in this context) may include the accessories of the translator who is a mediator 
(ISSN : 2536 - 9555)

representing feelings and emotions or descriptive scenes to transfer culture smile to the reader. The translator does his best to reproduce the text with its accessories as they are in quite a different language.

Literature translated from Arabic into English had a very small market and was confined to a limited audience before the only Arab laureate Naguib Mahfouz is awarded the Nobel Prize in 1988 (Altoma 2005). After that, there was a wave of interest in translating Arabic literary works in general and the translation of Mahfouz"s works in particular (Tresilian 2008). For example, Alkhawaja (2014) highlighted the number of Arabic translated literary works from Arabic into English between 1966 and 1988 to be 66, whereas titles translated between 1988 and 2008 are 288 which indicate a focus on the Arabic society and culture. A lot of studies are conducted in relation to translation equivalence and cultural problems. Whereas very rare studies are conducted in relation to Arabic English ones especially related to this type of folk (Mahfouz's novels). For Example, Kashgary (2011) points out that non-equivalence strategy may become more relevant than equivalence or "non-equivalence" becomes more equivalent than "equivalence; in translation of cultural Arabic text to English". In his study Braçaj (2015) claims that the more a translator is aware of complexities of differences between cultures, the better a translator s/he will be. At the same time, Dauod (2017) in another study explores the different definitions of translation as a process and as a product as well. Her study focuses on specific definitions that have been introduced by Arab scholars in the field of translation. She concludes that translation is not a mere substitution of texts among languages.

In a paper by Aldawood (2017), she tackles the issue of representing the target language's culture in the translation of the culture-specific elements of (فخاخ الرائحة) Wolves of the Crescent Moon), an Arabic novel written by Yousef Al-Mohaimeed the Saudi author. She argued that English translations of Arabic literary works are influenced by stereotypical representations of Arabs that were supported by the selection of works to be 
On Translating Culture-Bound Expressions in Naguib Mahfouz's The Thief and the Dogs and strategies: A Comparative Study in Arabic-English Translation Dr. Yousreya Ahmed Ali Alhamshary

مجلة وادي النيل للاراسات والبحوث الإنسانية والاجتماعية والتربوية (مجلة علمية محكمة)

translated and the strategies used in translation. She concludes that stereotypical images, manipulation, and domestication strategies are not necessarily presented in the translation of this work and that foreignization strategies are dominant in an era of easy access and increased communication with other cultures.

To explore translation equivalence in terms of the reader's response, Zhen (2016) intends to obtain a plausible account of theories and application regarding translation equivalence and other related fields. He proposes that the reader's response is the best answer embracing perspectives of recent developments in translation study in a wide communicative and cognitive frame of reference. Then, he proposes and elaborates on a more comprehensive model of translation equivalence, followed by detailed practice, analysis, and discussion of selected literary works of translation between the Chinese and the English languages. In another study, conducted by Guessabi (2013) on the cultural problems in translating Algerian novel from Arabic into English, concluded that translation is not only translating the words, the meaning, the rules of grammar, and the arrangement of words, but it is also translating the behavior of the society and cultural customs.

In parallel to that, several studies are conducted about the problems of translation of Naguib Mahfouz's literary works. Naguib Mahfouz is chosen as his works teem with great varieties and unique techniques. Mahfouz portrays life and social connections in terms of social coherence. Allen (1988, p. 3) states that "Mahfouz presents a newly found sense of realism and social connections". A lot of studies are focused on Mahfouz's Midaq Alley as Aziz (1993) conducts a study about the explicit and implicit reference and another study about pragmatic problems by Abd Alhafez (2003). Farghal and Borinin (1998) handle the translatability of politeness formulas in the English version of Mahfouz's Awlad Haritna using a pragma-linguistic approach. Al Gamal (2000) handles presupposition in the three English versions of Midaq Alley, Mirramar and Fountain and Tomb. Obidat (1998) 
(ISSN : 2536 - 9555)

has compared the translated English version of The Thief and the Dogs with the original Arabic text to highlight the differences in the stylistic choices of vocabulary and grammatical categories without any reference to the cultural problems found in the translation of the novel. Previous studies rarely handled the cultural side of the novels mentioned. Obeidat (1998) concentrates on similarities and differences in the structure of discourse and style of the two languages. The results of comparison in this study have shown that each text and its translation generate comparable proportions of entities on the three levels of abstraction. This goes with Nida \& Taber 's (1982) claim that the general proportion of specific to generic vocabulary is comparable in all human languages. Another study about discourse of grammatical shift in 'The Thief and Dogs is conducted by Khalil and Saad (2017). They conclude that the shift between grammatical discourses to another does not affect or disturb cohesion in the novel.

Another study by Salim \& Mehawesh (2013) investigate the translation of color idiomatic expressions in Mahfouz's novel "The Thief and the Dogs," and to what extent they are retained, wasted, or distorted. Finding out the similarities and differences between their meanings in both languages, the study also explores the different translation strategies applied in translating color idiomatic expressions in this novel. The study focuses also on the most common colors namely black, white, yellow, red, green, and blue.

It is clear from the previous studies that the works of Naguib Mahfouz have received much attention from investigators. However, there will be a lot of further studies as his works are very precious and need more to understand its deep messages to the reader. The Thief and the Dogs is written by the great Egyptian writer and translated into English by the American university in Cairo by Trevor Le Gassick and M.M Badawi in 1984. Trevor Le Gassick is a foreign critic who is well acquainted with Mahfouz' works. He refers to the novel in his introduction to the Midaq Alley (1975) as a marvelous work. He points out that with "The Thief and the Dogs, Mahfouz 
On Translating Culture-Bound Expressions in Naguib Mahfouz's The Thief and the Dogs and strategies: A Comparative Study in Arabic-English Translation Dr. Yousreya Ahmed Ali Alhamshary

مجلة وادي النيل للار اسات والبحوث الإنسانية والاجتماعية والتربوية (مجلة علمية محكمة)

... has changed from realist to impressionist and he used the 'stream of consciousness technique to pursue the thoughts and motivations of his central characters, ... It is a powerful and fast-moving work, a drama in which the killing of the hero is inevitable but tragic.

From the Arabic critics' point of view like Fatma Mussa (1965), "The Thief and the Dog" marks a turning point and a new stage in the career and development of Naguib Mahfouz as a writer. He uses, for the first time in Arabic Literature, a new literary technique which is a single character, the hero, Said Mahran, to dominate the entire story. The rest of the characters are significant only to the degree that Saeed allows them to occupy his thoughts. One of the daring moves which Mahfouz made towards the development of the Arabic novel in The Thief and the Dogs is the use of the stream of consciousness technique, the direct and indirect internal monologue, and the soliloquy.

\section{Aim and Methodology:}

The main aim of the present study is to find out the types of culture-specific items located in in Naguib Mahfouz's work "The Thief and the Dogs" and how the translation of them does not convey the right message of the novel and the image is not completely rendered to the reader because of the translation strategies used. This novel is chosen especially for it represents a great deal of the Egyptian society and reflects a part of the social problems in the Egyptian life nowadays like anarchy as a defense mechanism, the futility of human life, and utilitarian relationships. In addition, almost all the major literary critics have agreed that "The Thief and the Dogs" is one of Mahfouz's finest and most important works.

The data for this study was collected from Naguib Mahfouz's novel "The Thief and the Dogs" and its English translation. The corpus of the present study consists of total (158) Arabic cultural bound terms, Classified into five categories. They 
(ISSN : 2536 - 9555)

are (18) religious, (14) historical, (74) ecological, (32) psychological and (20) material cultural bound terms with their English translation. A list of abbreviations is used, and this list is located at the end of the study (appendix 1). Baker's (2018) approach is used as a tool to decide the translation strategies used and analysis of the five chapters chosen for the study. The first five chapters have a lot of descriptive scenes and most problematic cultural bound terms are included in them. The cooperation of a native speaker in the translation reduces the problems of translation, however, reduces the enjoyment of the reader who receives an incomplete meaning of the image. The study may help future translators doing their job appropriately.

\section{Analysis and Discussion}

The data for this study has been obtained from the Arabic and English version of The Thief and the Dogs. There are a lot of cultural bound terms in the novel and are translated using different strategies as will be represented in the discussion part. Vinay and Darbelnet (1995), and House (1977) argue that the context of each text should be well identified and considered to overcome problems of translation and that the appropriate equivalence arises from the correct recognition of the situation where the text is used. The following types of cultural bound terms have been found.

\section{Religious Cultural Bound Terms (RCBT)}

They are the cultural bound terms referring to Egyptian religious aspects and words representing what they believe. The corpus of this cultural fold consists of (18) examples. Some of them are as follows:

- The expression "، كل خلاف حل في الثرع...والتفاهم خير... نعم (NM, p.11) is translated as "'No. But there is a solution to every disagreement. In the sacred law." "And it's best to reach an understanding," someone else.... (TLG, p.17). Lexically, the word "disagreement" means "a situation where people have different opinions about something and often argue". The expression "disagreement" and "understanding" are both away 
On Translating Culture-Bound Expressions in Naguib Mahfouz's The Thief and the Dogs and strategies: A Comparative Study in Arabic-English Translation Dr. Yousreya Ahmed Ali Alhamshary

مجلة وادي النيل للار اسات والبحوث الإنسانية والاجتماعية والتربوية (مجلة علمية محكمة)

from the meaning of the word "الثشرع" that means here the Qur'aan that decide the responsibility of bringing up children in case of parents' divorce. What they are talking about here is the ethics not the "sacred law" as they continue to remind Said that he is almost out of jail and he cannot bring up his daughter as her mother does, even if the "sacred law" sentenced the girl to go and live with him. They are referring to social values by the two expressions mentioned above.

- The second example is "... عند الاجل لا ينفع مخبر و لا جدار " (NM, p.12) is translated as "When your hour arrives neither detective nor walls will do you any good.... (TLG, p. 18). The meaning is when can kill you nobody or nothing will help you. The general meaning here by the word "hour" is an Arabic culture expressing death time. In the target language it can be read differently as no lexical reference to that meaning or in an idiom. The translator used literal translation for the word's "hour", "walls" and "detective".

- The expression " (NM, p. 13) is translated as "worry-beads... (TLG, p. 18). The beads are not the same Arabic "swبحه" for beads are used in Roman Catholics prayers. The lexical meaning of the word is "a string of beads that are used by some Roman Catholics for counting prayers as they say them". It is better to add any word to indicate the cultural religious meaning of it or use the word "rosary" which lexically means in Arabic "مسبحه". And the verb "play" also is not expressing the prayers done with the beads. The real expression is being annoyed and excited by fear from Said reaction. The translator loaned the English word to suit the English culture.

- The expression " ...." (لقسمة و النصبي" (NM, p. 14) is translated as "It was partly fate and circumstances... (TLG, p.19). In the Egyptian culture this expression is used when someone missed something he likes to have as a type of regretting his fortune. Ilish told the people that meaning that he did not betray Said but he married his wife and brought up his daughter because of the circumstances and duty according to them. In another place 
(ISSN : 2536 - 9555)

"البخت و القسمة... (NM, p. 26) is translated as "luck and good fortune... (TLG, p.30)". The Arabic expressions are the same, but the English are different. The word "circumstances" means the conditions and facts that relate to and affect a situation, an event, or an action of a person's life, especially the money they have. However, the Arabic meaning has nothing to do with conditions that can be changed by people, but it is Allah's fate.

- The Arabic expression " ... يختم الصلاة" (NM, p. 22) is translated as "concluding his prayer... (TLG, p.26). The verb "conclude" lexically means to come to an end; to bring something to an end which means that it is a part of the prayer. It is not a part of the prayer, but Muslims do it after each prayer. In another place the translator used another word "recitation" which means an act of saying a piece of poetry or literature that you have learned to an audience.

- The expression " السلام عليكم يا سيدى ومولاي... (NM, p. 22) is translated as "Peace be upon you, my lord and master... (TLG, p. 26)". The very simple expression "سيدي ومو لاي" do not mean lord or master as the English expression means that he is working for the "sheikh" but the Arabic mean does not exceed more than greeting words for a religious man. The word "master" lexically means " a man who has people working for him, often as servants in his home "or" a person who is skilled at something "or" a male teacher at a school, especially a private school" or " the captain of a ship that transports goods" or" a famous painter who lived in the past" which all are far from the intended meaning of the Arabic "سيدى ومو لاي"." It is better to be taken as it is in Arabic "Mawlay".

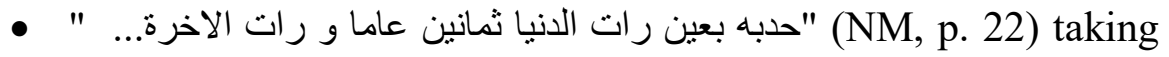
about a man aged 80 years and recognizes the end of destination or death and worked for. The meaning in English "and glimpsed the next (TLG, p.26)" does not give the right meaning of being a religious man recognizing his end for a long time.

- The expression " . هذا صوت زمان" (NM, p. 22) is translated as " the "sheikh" in a voice like Time... (TLG, p.27). The meaning 
On Translating Culture-Bound Expressions in Naguib Mahfouz's The Thief and the Dogs and strategies: A Comparative Study in Arabic-English Translation Dr. Yousreya Ahmed Ali Alhamshary

مجلة وادي النيل للاراسات والبحوث الإنسانية والاجتماعية والتربوية (مجلة علمية محكمة)

in Arabic is the voice he heard before or like memories in his mind, but the English one likened the voice as time or sound of time. The right meaning "is a very wise man".

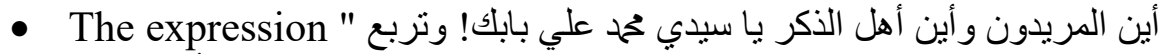
"الحصيرة.... (NM, p. 22) is confusing. It is translated as" And the disciples, the men chanting the mystical "dhikr", "O master, the Prophet is at your gate!"--where were they now?... (TLG, p.27). The meaning in Arabic is that is remembering his father on seeing the Sheikh and tried to remember the face and the voice asking where the people chanting are now, they are not there to say, "we are on the door of the prophet". The English is not like that at all it is translated as if the prophet is there standing on the door of the lord "O master, the Prophet is at your gate!".

- The expression " (NM, p. 25) is translated as "in trouble... (TLG, p.29). The English expression is more general as it includes any type of problems but the Arabic one lean on the most difficult problems that cause psychological troubles.

- The expression "يا سيد الاحياء (NM, p. 21) is not translated as there is no equivalence for this aspect in the English language, though the translator may add an adjective to represent the target meaning which is honoring the "Skeikh".

- The expression " (NM, p. 22) is translated as " my lord and master". The lexical meaning of the word "master" means "a man who has people working for him, often as servants in his home" and additional other meanings like a man who control work or teacher ...etc. the reader may be confused as the sheikh already has some people come to him "dhikr". The translator does his best to give more explanation according to the context and changed the required text to adapt the right meaning. As an example, in the idiom "الف نهار ابيض which means "white day" expressing happiness in the Egyptian culture. The translator translated it into "what a pleasant surprise. The translator sees it necessary to use the strategy of 
مجلة وادي النيل للاراسات والبحوث الإنسانية والاجتماعية والتربوية (مجلة علمية محكمة)

(ISSN : 2536 - 9555)

cultural approximation as the literal translation "one thousand white days" will have no sense in the context.

In the above examples and many others in the novel, it is required to the reader to have a social cultural background to get the right message of the translated text. This goes with Salim \& Mehawesh (2013) who show how important context is as far as meaning is concerned. It is also one of the reasons why a translator should take into consideration the circumstances in which items uttered.

\section{Historical Culture Terms}

A lot of historical events and places or names are represented in the novel and requires the reader to know some about the Egyptian history to recognize them. The corpus of this cultural fold consists of selected (14) examples. Some of them are as follows:

- Jobs like the "المخبر" (NM, p. 10) This job in the time of the novel in the Egyptian culture is handled by a man who sits at café or follow criminals and at the same time works for the government where in the English society it is a private work and can be done by a man or a woman. Names of persons like "Rauf Elwan رؤوف علوان " representing journalists currently and their manner of work. Also, the word " ... تتابله/ موظفوا الحكومه (NM, p. 59) are translated as "lazy" meaning unwilling to work or be active ; doing as little as possible / bureaucrats... (TLG, p.39)" meaning "an official working in an organization or a government department, especially one who follows the rules of the department too strictly" and both are contradicting in meaning but representing some employees in Egypt at this time.

- All names in the novel are loaned and representing the lower class like Nabawiyya, Ilish, Bayaza and Sanaa from the Egyptian society. Places like Abaseya Square "بs "ميدان العباسيه",

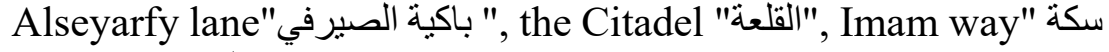

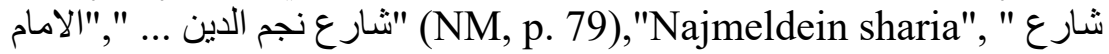

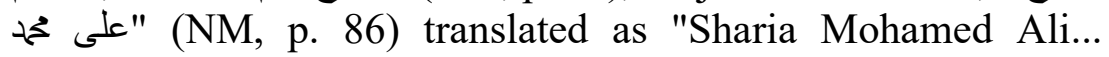
(TLG, p.54)". "جريدة الزهراء" (Alzahraa Journal" and Kasrelnile bridge are all famous places related to famous events in Egypt and anybody visits Egypt should know them. 
On Translating Culture-Bound Expressions in Naguib Mahfouz's The Thief and the Dogs and strategies: A Comparative Study in Arabic-English Translation Dr. Yousreya Ahmed Ali Alhamshary

مجلة وادي التيل للاراسات والبحوث الإنساتية والاجتماعية والتربوية (مجلة علمية محكمة)

- Types of buildings also represent the cultural places like " البواكي ..." (NM, p. 9) which is translated as "arcades" that means in English a covered passage with arches along the side of a row of buildings (usually a row of shops/stores) or a large building with several shops/stores in it. The word "الثيش... "(NM, p. 10) translated as "shutters" which means one of a pair of wooden or metal covers that can be closed over the outside of a window to keep out light or protect the windows from damage. The Egyptian old buildings are famous for this type of windows or balcony. The word "...०والكو" (NM, p. 83) is translated as " the hall in the wall" which is not identified in the English culture. The word "السلاملك" (NM, p. 37) is translated as "main entrance... (TLG, p.25)". This word in Arabic Egyptian culture means a main place used for meeting of men during the period of Khedawy Abass Helmy the second. While main entrance means the front part of a house which may be a room or open place "النراس". Another word is "الفراندا" is translated as it is in Arabic "verandah" which means a platform with an open front and a roof, built onto the side of a house on the ground floor.

- Other places related to cultural entertainment in Egypt like صحاري " (NM, p. 100), "Alzayat circus" and " سرك الزيات..." "زينهر " "Zeinhom desert" and "..... سيدي الاربعين " (NM, p. 103),"Sedy Alarbein" and "Agaty, Tsepas, Manoly" and ... (Nسر الجلاء" (NM, p. 136) "Algallaa Bridge". All these names are well known in Egypt as cultural representative of Egyptian society.

\section{Ecological culture bound terms (ECBT).}

Ecology refers to geographical features which are specific for their original countries and they are politically and commercially valuefree (Newmark, 1988 p. 96). They are the cultural bound terms related to environment or Egyptian ecology including work or leisure. There are a lot of these examples (74) in the novel. To illustrate more about the Egyptian cultural context, we shall consider the following example: 
(ISSN : 2536 - 9555)

- The word "... مع " (NM, p. 10) in the Egyptian society means the man who works in a café or the very old man in the very lower-class social status is translated as "Mr" which means in the English society a title that comes before a man's family name, or before his first and family names together or a title used to address a man in some official positions.

- The idiom " (الف نهار ابيض... (NM, p. 10) which means "white day" expressing happiness in the Egyptian culture. The translator translated it into" how marvelous... (TLG, p.11)". The translator sees the literal translation "one thousand white days" will have no sense in the context.

- The expression " .... (NM, p. 11) is translated as "come into the shop and have a cold drink to celebrate (TLG, p.14)". The word "دكان" in Arabic means a small shop in a very poor area while in English the word "shop" means " a building or part of a building where you can buy goods or services" without referring to the status of the area whether rich or poor. Again, the difference between the word "شربات "and "cold drink" is clear as the first is being drunk only in happy occasions the other word "cold drink" is used on every occasion. That is why the translator added "to celebrate" to identify that the occasion is happy for the situation.

- The expression " .... (NM, p. 13) is translated as "only harmful deeds can shame a man... (TLG, p.13)". The lexical meaning of the word "harmful" means "causing damage or injury to somebody/something, especially to a person's health or to the environment" which is a way from shame or immoral deeds meant in the Arabic culture. This expression is in Arabic defending man's identity in the society. The word "العيب here means being a thief only as being corrupted only to be a thief. In English harmful deeds are not specified or referred to so any deeds according to the English society is acceptable.

- The expression " الحال لا بسر عدو و لا حبيب... (NM, p. 15) which indicate a very bad condition and may be attached with sadness is translated as "she was in a terrible predicament... (TLG, 
On Translating Culture-Bound Expressions in Naguib Mahfouz's The Thief and the Dogs and strategies: A Comparative Study in Arabic-English Translation Dr. Yousreya Ahmed Ali Alhamshary

مجلة وادي النيل للار اسات والبحوث الإنسانية والاجتماعية والتربوية (مجلة علمية محكمة)

p.14)". the meaning in English is "a difficult or an unpleasant situation, especially one where it is difficult to know what to do".

- The expression " ... Tزى الثبطان" (NM, p. 15) which means stop thinking or doing what you are doing or thinking in is translated literally as "shame the drivel".

- The word " ... "شاطره" (NM, p. 17) which means a girl from the poor lower class in the Egyptian society is translated as "child" which means in English "a young human who is not yet an adult not identified as girl or boy and not identified as poor or rich".

- The expression " ... 'يضع سره في اضعف خلقه" (NM, p. 25) which means in the Egyptian context that the weakest person can give some help to the strongest is translated as "God reveals his secrets to his tiniest creatures" which is very different in meaning.

- The expression " ... أعيش بعرقي وكدى" (NM, p. 42) which means I have my own work that I have my income from or live with is translated literally as "I live by the sweat of my brow". The translator depended on the sweat come from work only but in Egypt it may come as result of hot day or shameful situation.

- The expression ".... " لا يعرف رأسه من رجليه (NM, p. 64) which means in Egypt that he is unaware may be because of overloaded work or very bad situation or even sudden events is translated as "dead drunk... (TLG, p.42)" which means that the person drunk to the status of being unaware.

- The expression " ...." (NM, p. 65) which means a very precious thing is translated idiomatically as "real catch or poor fish... (TLG, p.42)".

- The expression " Tلو رجل... (NM, p. 86) which means having an amount of money in return of leaving the place one live in is not translated as the translator did not find any expression equivalent to it. 
(ISSN : 2536 - 9555)

- The expression " ... با كسوفى" (NM, p. 92) which means I am ashamed of is translated as "I'm sorry ... (TLG, p.57)" which is considered an apology in English.

- The expression " .... Tحطك في عيوني واتكحل عليك" (NM, p. 95) which means in Arabic that one well takes care of someone is translated as "keep you hidden all right... (TLG, p.59)". The translator considered the context meaning that Saeed should hide himself and translated it from this point of view while the real meaning also is that Nur loved him and is granting him her real love with care as she did not know in this situation that he is running away.

- The expression " .... يعجبه العجب ولا الصيام في رجب" (NM, p. 116) which indicate in Arabic that someone is not happy about any deeds of his surround is translated as "nothing impresses the police... (TLG, p.73)". The verb "impress" means in English you feel admiration for someone or something. The real meaning in the context is that nobody can deceive the police as he knows every trick that can be done from the thieves.

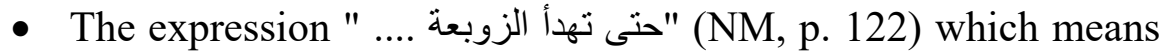
that he should hide himself tell the police forget the case and be busy by another is translated literally as "wait the storm to blow over... (TLG, p.76)".

\section{Psychological culture bound terms (PCBT).}

They are the cultural bound terms related to motives or psychological status of the novel's characters or of Egyptian people. The selected corpus of this cultural fold consists of (32) Examples. Some examples are as follows:

- The expression " في الجو غبار خانق/ حر لا يطاق (NM, p. 7) translated as " There was stifling dust in the air/ almost unbearable heat" The Thief and the Dogs (TLG, p.13), explains the nature of the Egyptian environment at this time of the year but at the same time expresses the feeling of a man getting out of jail and breathing freedom. A contrasting feeling like exactly what he has in his life a betrayal by his 
On Translating Culture-Bound Expressions in Naguib Mahfouz's The Thief and the Dogs and strategies: A Comparative Study in Arabic-English Translation Dr. Yousreya Ahmed Ali Alhamshary

مجلة وادي النيل للار اسات والبحوث الإنسانية والاجتماعية والتربوية (مجلة علمية محكمة)

friend and wife (dust and heat) and his daughter Sanaa (the air of freedom.

- The expression " ..... ها هي الدنيا تعود" (NM, p. 7) which means in Arabic that Saeid now has his life again and can start again is not translated in the context.

• followed by "مبارك للأصدقاء والاحباب " الحمد الله على سلامتلك" (NM, p. 10) which is in the context of someone who gets better after being sick or gets back home is translated as " Thank God you're back safe and sound" and " We congratulate ourselves, being your close friends" The Thief and the Dogs (TLG, p.16)، do not give the same meaning in Arabic. The second sentence mean that only people who loves you will be happy for you being back again. The English expression is that they are very happy for him as being his loyal friends only. While in the previous description "he found himself surrounded by a crowd--his enemy's friends, no doubt".

- The translator in another place does not translate or give a meaning but replaced the expression by the people caused it like " ... الخيانة" (NM, p. 8) which means betrayal in English when replaced by "what Nabawiyya and Ilish had done... (TLG, p.9)".

- The expression " ... الكدر" (NM, p. 9) which means in Arabic sadness or misery is translated as "darkness... (TLG, p10)" which means "the state of being dark, without any light" or evil in general. The same is done with the word " ... الكرب" (NM, p. 25) which means problems or sadness is translated as "In trouble... (TLG, p.20)".

- The expression " لكمه برحمده".. (NM, p. 26) which means using his hand to hit him as the word "رحم" means "the front part of the hand". It is translated as "punished him gently... (TLG, p. 20)". The status of punishment is not recognized in the Arabic context while is defined as "gently" in English.

- The expression " يا ارض احفظى ما عليكي." (NM, p. 57) is used in Arabic to indicate that someone is very beautiful and well 
(ISSN : 2536 - 9555)

dressed. The translator did not translate it in the English context.

- The expression "مسكين... (NM, p. 70) is used in Arabic to express excessive fear. The translator translated it as "his knees shaking" which may be because of excessive cold weather.

Material culture bound terms (MCBT).

For Newmark (1988 p. 97), this category includes the most widespread cultural elements in translation. He proposes four main sub-elements under the material culture including clothes, food, houses and towns, and transport. However, food terms are widely used in various settings. In this context, they are cultural bound terms related to Egyptian food, clothes, houses ...etc. the corpus of the cultural sign consists of selected (20) items. Examples of these sings are as follows:

- The expression " ... البيوت و الدكاكين (NM, p. 7) which is one of the cultural bound terms of Egyptian life does not have equivalence in the target language and the translator does not use any of words like shops and houses. This may distort the meaning.

- The word "..... الترام" (NM, p. 9) is representing the Egyptian culture till now. The translator used "tramcars... (TLG, p.10)"

- Other expression like " "دقيق العيد...ص which is only for the feast is translated as "flour to make sweetmeats for the feast... (TLG, p.10)" using the paraphrasing strategy.

- The expression "جلباب مقلم (NM, p. 12) is translated as "striped garment (TLG, p.12)" men used to wear garment and a coat to indicate their job "مخبر" with the "police boots" and the translator used the word garment which lexically means in the Arabic outer garment for a female.

- The Egyptian coin at this time is the "مليم... " (NM, p. 15) or the French word " millime", however, the translator used his smallest coin to express the value of the Egyptian coin as he used the word "penny... (TLG, p.14)" which in Arabic is 
On Translating Culture-Bound Expressions in Naguib Mahfouz's The Thief and the Dogs and strategies: A Comparative Study in Arabic-English Translation Dr. Yousreya Ahmed Ali Alhamshary

مجلة وادي النيل للاراسات والبحوث الإنسانية والاجتماعية والتربوية (مجلة علمية محكمة)

bigger than the value of "millime" "قرش" and translated the later as small coin in another place ((TLG, p.54). The same is done with the word "الحصر..." (NM, p. 22) as the translator used "rush mats... (TLG, p.17)". Another expression is ".... النصبة النحاسية" (NM, p. 58) which is used in the Egyptian café to smoke the translator could not find an alternate word and omit it. The Arabic word " ... (NM, p. 78) which mean a place under the stairs where people can sleep and live in is translated as the "bottom of the stair... (TLG, p.48)" which mean the starting point of the stair.

These are examples of the material related to the Egyptian culture and how the translator rendered them. The novel is full of other expressions or material cultural bound terms that may affect the message of the story and how the original writer is successful in representing the Egyptian society however the translated version's message is less effective to the reader.

\section{Results:}

From the previous analysis, results found can be represented as follows:

Concerning the corpus of the study, cultural bound terms can be classified as indicated in table (1) into five types. As the novel handles the social and cultural side of the Egyptian society, the ecological cultural bound terms form (74) items out of the total number of the corpus (159). Naguib Mahfouz is keen to represent this side followed by the psychological cultural bound terms as the novel contains a lot of feelings and this side is very important in forming the Egyptian reader at this time. The less representative cultural bound terms are those related to history due to the type of novel. 
مجلة وادي النيل للاراسات والبحوث الإنسانية والاجتماعية والتربوية (مجلة علمية محكمة)

(ISSN : 2536 - 9555)

Table (1): Types of Cultural Bound Terms

\begin{tabular}{|c|l|c|c|}
\hline No. & Types of cultural bound terms & $\begin{array}{l}\text { No of } \\
\text { examples }\end{array}$ & percentage \\
\hline 1 & HCBT & 14 & $8 \%$ \\
\hline 2 & RCBT & 19 & $11 \%$ \\
\hline 3 & ECBT & 74 & $46 \%$ \\
\hline 4 & PCBT & 32 & $20 \%$ \\
\hline 5 & MCBT & 20 & $12 \%$ \\
\hline Total & & 159 & $100 \%$ \\
\hline
\end{tabular}
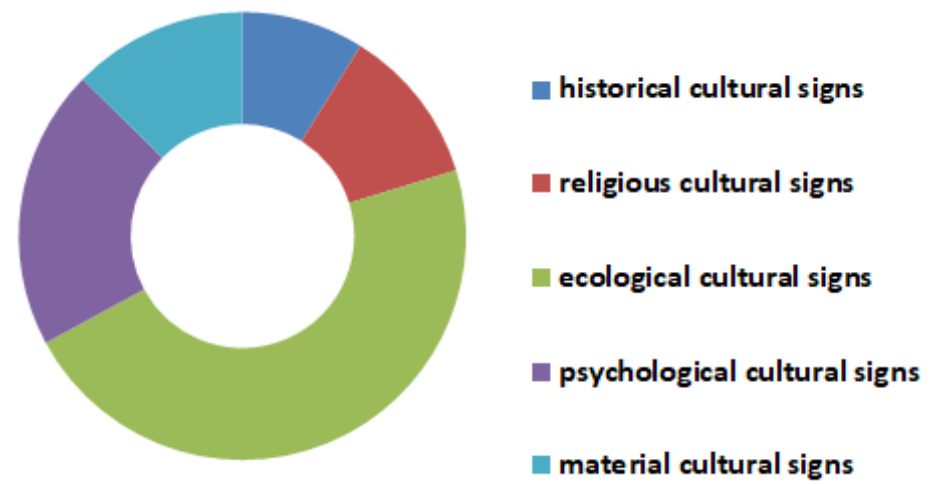

Figure (1): Types of Cultural Bound terms

From the table and the graph, the ecological cultural bound terms are the most frequent cultural bound terms (46\%) due to the nature of the novel and the context it deals with besides the social class it represents. The second frequent cultural bound terms are the psychological cultural bound terms $(20 \%)$ which also represent the spiritual and status of the Egyptian character. Following this are the material cultural bound terms $(12 \%)$ that differentiate the Egyptian society and give the special taste for the social life. Following this is the cultural religious bound terms (11\%). The least frequent cultural bound terms are the historical ones $(8 \%)$ as the target of the novel is to represent the real social cultural life of this class, not to focus on the history of the period. 
On Translating Culture-Bound Expressions in Naguib Mahfouz's The Thief and the Dogs and strategies: A Comparative Study in Arabic-English Translation Dr. Yousreya Ahmed Ali Alhamshary

مجلة وادي النيل للاراسات والبحوث الإنسانية والاجتماعية والتربوية (مجلة علمية محكمة)

\section{Some differences are found in the translation like:}

This section is about the differences found in the TT. They may not be effective differences however they affect the real message of the original text.

- In the expression (... Iنبويه عليش' كيف انقلب الاسمان اسما واحدا؟ (NM, p. 8)

Nabawiyya, Ilish. Your two names merge in my mind. (TLG, p.7)

- The source text uses a question type to indicate wonder of how both Nabawiyya and Ilish got together and get married he cannot believe that. Whereas the English version uses a statement indicating that there is no wonder.

- The expression " Tلعكما تترقبان في حذر" (NM, p. 8) is translated as "You will be watching now... (TLG, p.7)", which is not equivalent to the actual meaning of the Arabic version. The embedded meaning in the Arabic text is that is now free and Ilish and Nabawiyya do not know that he is free or may they know and watch what will happen carefully. The English version indicates that is talking to himself and that they will suffer from his freedom.

- The translator adds a question about Sanaa which is not in the Arabic version when saying " ... وسناء اذا خطرت في النفس" (NM, p. 8) And Sanaa? What about Sanaa? (TLG, p.7)". The addition may be for illustration about the girl and to interest the reader to ask about the character. The expression "وتدرجت في النمو وهى صورة غامضه... (NM, P. 8) translated as "bit by bit she'd taken shape, like an image in a dream... (TLG, p.7)" holds a different meaning the dream you may have image you know but he never sees her at all.

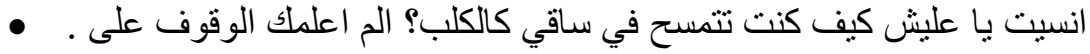
"قدمين؟ (NM, p. 8) Have you forgotten, Ilish, how you used to rub against my legs like a dog? It was me, wasn't it, who taught you how to stand on your own two feet, (TLG, p.7).

- The expression to stand on your own two feet is word by word translation where in Arabic it refers to the man who become strong and depend on himself where in English it 
(ISSN : 2536 - 9555)

refers to the verbal action of standing in two feet and no image in that expression. The translator adds the sentence" where what Nabawiyya and Ilish had done would be no more than o memory, odious, but almost forgotten? As an alternate to "الخيانة" may be to indicate the pain feels. The Arabic expression "جامع الأعقاب" is only known for the young Egyptian boys who cannot buy cigarettes but collect them after people smoke.

- The translator uses addition as a technique in places where أشهد أنى " no need for adding like that found in the expression "أكرها... (NM, p. 8) where the translator added the word "all" when saying "I swear I hate you all ... (TLG, p.15)". at the same time the translator adds the word "please" in " "تطلق" (NM, p. 55) " No No please don't shoot... (TLG, p.64)". We do not have in the source text a word like من "مجر"

"ارجوك"مفضلم" Also, the translator adds the same expression in an utterance between Nur and when saying " (NM, p. 122) saying "Nur, he pleaded, "please don't torture me. I am terribly depressed. ... (TLG, p.135)". More added lexical items are the word "again " and the word "too" without considering the context or the meaning behind the Arabic text in the

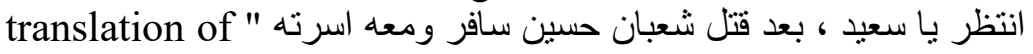
"دون ان يخبر احدا عن وجهته، كان مرتعبا وكانت المر آه مرتعبة... p. 106) in saying " "Wait" he pleaded. "And after Shaban Husayn was killed he took his family away again. He did not tell anyone where He was scared, all right, and his wife was, too. ... (TLG, p.119-120)". The same is done with the translation of " وتراجع في فزع. واوغل بين القبور والنباح يشتر "ويقترب... (NM, p. 139) where the translator adds the word "again" without any addition to the meaning "started back in fright, darting in again between the tombs while the barking grew louder. ... (TLG, p.156).

- In the expression

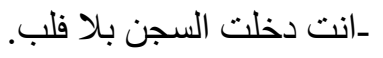


On Translating Culture-Bound Expressions in Naguib Mahfouz's The Thief and the Dogs and strategies: A Comparative Study in Arabic-English Translation Dr. Yousreya Ahmed Ali Alhamshary

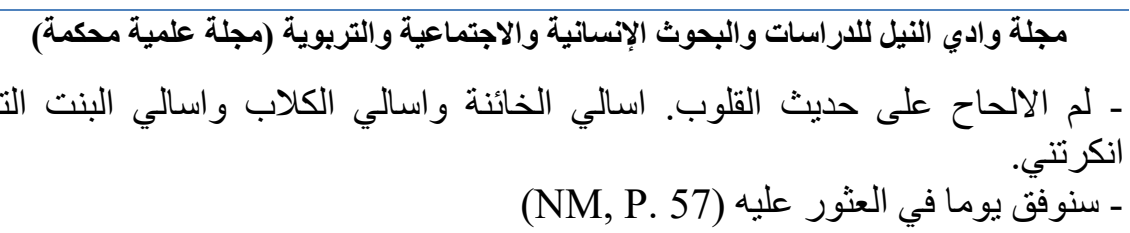
The translator renders it as

- "You were heartless long before you ever went to jail."

- Why does she harp about affection? She should talk to that treacherous woman, and the dogs, and the little girl who rejected me.

- "One day we'll succeed in finding it," he." ... (TLG, p.60)"

- In the Arabic version, it is very easy to figure out the participant who produced each sentence whereas in English the translator used the pronoun "she" which may be understood as if Said is talking to himself, but he is really talking to Nur. The translator may render it in this way for the female clue in the Arabic word (اسالي). This way of rendering the text has distorted the meaning and changed the structure of the context. The last sentence of Nur- according to the Arabic utterance- is uttered by Nur to win 's heart but the translator has attributed it to.

- There is a semantic difference between the two words "رده" and " as the first one means slightly open but the second one means close in the translation of " دفع باب مسكن "الثيخ فأطاع دون مقاومه ، ودخل ورده ور اءه... (NM, p. 63) as " He pushed the sheikh's door, met no resistance, entered, closed it behind him... (TLG, p.74).

- Another semantic difference is found in the sentence " توقف (NM, p. 9) in the translation "He let the man catch up with him; they hello. ... (TLG, p.16)" as the expression " hello" is not the same meaning as "shook hands". The first is a speech act but the last is refers to a physical activity.

- The word "معلم" is repeated in the Arabic text and it is only used for the Egyptian man who has a café or a restaurant or a workshop as mentioned by Enani (1997. p.21). the title 
(ISSN : 2536 - 9555)

"Mr" is used before the name of any man or in talking. Thus, it is not culturally appropriate to use it throughout the translation to be alternate to 'معلم" or "friends" as an alternate to "اخوان" which is used to talk to people in the Egyptian street in general as in "اشكرك يا معلم طرزان "(NM, p. 45) "thanks, Mr Trazan. (TLG, p.55).

- The Arabic text " ...!"اسكت انت تظن ان حبل المشنقة لهو ولعب (NM, p. 93) is translated as "shut up, will you! You think a hangman's rope is some sort of a joke! (TLG, p.107) where the translator by using a question tag, have turned it into a request whereas the order is given in a direct form.

- The expression " لا تؤاخذني.. (NM, p. 97) is not an equivalent to the translated text "Please, don't be angry with me ...the thief and dogs (TLG, p.111) as it can easily be "excuse me" especially the translator completes using "he apologetically".

- The expression " حتى تهدا الزوبعة (NM, p. 98) did not consider the context and culture of the text. It is in case of you want to calm down both sides in a problem or in the situation of the sentence it meant to wait till things calm down, but the translator rendered it as a real storm when saying "for the storm to blow over" ... (TLG, p. III)

- In the expression " ... يا خبر ابيض (NM, p. 142) translated as "You don't say! You are hungry, then! ... (TLG, p.138) the translator uses a statement attached to a question tag, instead of providing the equivalent of the request of from Trazan not to be surprised.

- The Arabic expression " "يا خبر ابيض... (NM, p. 128) is translated as "Dear me! Hungry ((TLG, P. 226). Egyptians say "يا خبر ابيض" or "white news" as an expression of surprise about a piece of news, in the same context they say "يا خبر اسود" or "black news" in reaction to bad news. The translator used cultural substitution "dear me", which is a polite exclamation expressing surprise and sympathy, because the color idiom " " با خبر ابيض has no exact equivalence in English. 
On Translating Culture-Bound Expressions in Naguib Mahfouz's The Thief and the Dogs and strategies: A Comparative Study in Arabic-English Translation Dr. Yousreya Ahmed Ali Alhamshary

مجلة وادي النيل للاراسات والبحوث الإنسانية والاجتماعية والتربوية (مجلة علمية محكمة)

- The translator uses the word "fox" instead of "snake" in the

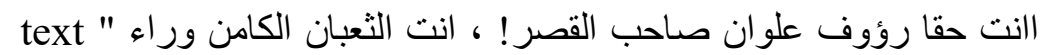

"حملة الصحف؟! (NM, P. 99) as in "shouted in anger to the darkened room: "Are you really the same one? The Rauf Ilwan who owns a mansion? You're the fox behind the newspaper campaign... (TLG, p.113-114)". However, the translator uses a question mark in the first two sentences in contrast with the Arabic version. This may distort the meaning and the message from the text.

- The word "الحداه" is well known to the Arabic people as an animal catching birds and pigeons but the translator used "eagle" as an equivalent to it in the context" تدبر امرك ثم تتقض "كالحداة... (NM, p. 59) "you must wait until you have arranged things, then swoop like an eagle ... (TLG, p.69)".

- The word "شاطره" can be translated with different expressions like "active", "professional" or "clever" which can be to some extent confusing. At the same time the expression "شربات" the literal translation is "syrup" but the actual required meaning is "so sweet". The word "شربات", "sharbat" is indicating a social custom meaning a sweet drink that all people have in happy occasions only but not a soft drink like Pepsi. However, in English they may have soft drinks in happy occasions or other drinks like wine which is in Arabic a shameful drink only corrupted people have it.

\section{Translation Strategies Used in the Translation of The Thief and} the Dogs.

According to Baker's (1992) taxonomy seven types of translation strategies used to translate cultural bound terms have been found. 
مجلة وادي النيل للاراسات والبحوث الإنسانية والاجتماعية والتربوية (مجلة علمية محكمة)

(ISSN : 2536 - 9555)

Table (2): types of strategies

\begin{tabular}{|c|l|c|c|}
\hline no & Types of translation strategies & $\begin{array}{c}\text { Number of } \\
\text { examples }\end{array}$ & Percentage \\
\hline 1 & Translation by a more general word & 23 & $14.4 \%$ \\
\hline 2 & $\begin{array}{l}\text { Translation by a more neutral/less expressive } \\
\text { word }\end{array}$ & 29 & $16.3 \%$ \\
\hline 3 & Translation by cultural substitution & 24 & $15 \%$ \\
\hline 4 & $\begin{array}{l}\text { Translation using a loan word or loan word } \\
\text { plus explanation }\end{array}$ & 19 & $11.9 \%$ \\
\hline 5 & $\begin{array}{l}\text { Translation by paraphrase using a related } \\
\text { word }\end{array}$ & 38 & $23.6 \%$ \\
\hline 6 & $\begin{array}{l}\text { Translation by paraphrase using unrelated } \\
\text { words }\end{array}$ & 17 & $10.6 \%$ \\
\hline 7 & Translation by omission & 12 & $7.5 \%$ \\
\hline & Total & 159 & $100 \%$ \\
\hline
\end{tabular}

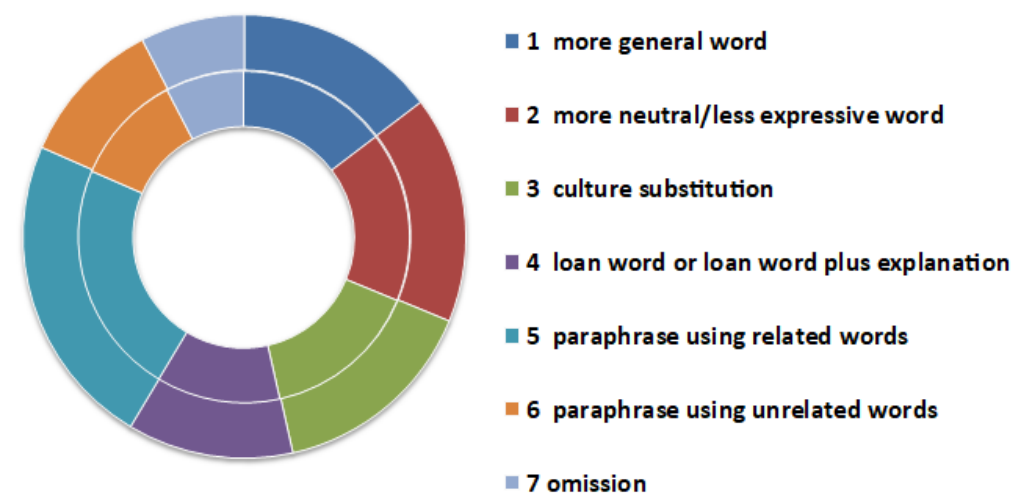

Figure (2): percentage of each strategy used.

Based on Baker's (1992) theory, there are eight strategies, but the researcher just found seven strategies employed in the English version. Those are translation by a more general word, translation by a more neutral/less expressive word, translation by cultural substitution, translation using a loan word or loan word plus explanation, translation by paraphrase using related word, translation by paraphrase using unrelated words, and translation by omission.

According to the data presented in table (1) selected items of the study consist of (159) ones. There are (23) items (14.4\%) belong to Translation by a more general word, 26 items $(16.3 \%)$ 
On Translating Culture-Bound Expressions in Naguib Mahfouz's The Thief and the Dogs and strategies: A Comparative Study in Arabic-English Translation

Dr. Yousreya Ahmed Ali Alhamshary

مجلة وادي النيل للاراسات والبحوث الإنسانية والاجتماعية والتربوية (مجلة علمية محكمة)

belong to translation by a more neutral/less expressive word, 24 items $(15 \%)$ belong to translation by cultural substitution, 19 items $(11.9 \%)$ belong to translation using a loan word or loan word plus explanation, 38 items (23.6\%) belong to translation by paraphrase. From 159 examples, there are 17 items $(10.6 \%)$ belong to translation by paraphrase using unrelated words, and finally 12 items $(7.5 \%)$ belong to translation by omission.

Translation by a More General Word (superordinate)

This strategy is one of the commonest strategies for rendering many types of non-equivalence, particularly in propositional meaning. It works equally well in most, if not all, languages, since the hierarchical structure of semantic fields is not language specific. The corpus contains (23) selected examples as follows:

Table (3): Translation by a More General Word (superordinate)

\begin{tabular}{|l|l|l|l|l|l|l|l|}
\hline No. & $\begin{array}{l}\text { Type of } \\
\text { strategy }\end{array}$ & HCBT & RCBT & ECBT & PSCBT & MCBT & $\begin{array}{l}\text { Total } \\
\text { examples }\end{array}$ \\
\hline 1 & $\begin{array}{l}\text { A More } \\
\text { General Word } \\
\text { (superordinate) }\end{array}$ & 1 & 4 & 13 & 3 & 2 & 23 \\
\hline
\end{tabular}

1 A More General Word (superordinate)

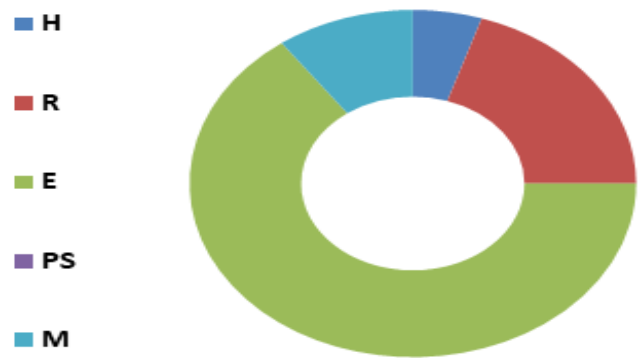

Figure (3): Translation by a More General Word (superordinate)

As represented in the previous table, only one historical cultural sing in the expression " تنابله / موظفو ا الحكومة " (NM, p. 59) where the translator uses more general expressions like "lazy and bureaucrats" where the meaning is more general than the Egyptian 
(ISSN : 2536 - 9555)

society. The cultural religious bound terms are represented in four positions " (ضعف الطالب و المطلوب (NM, p. 27) translated in general as" weak are the seeker and the sought... (TLG, p.20)" where the translator does not refer to the religious aspect of the sentence. The other expression is using " توضأ واقرا" (NM, p. 28) translated as "wash and read" as both verbs have different meaning in English. Wash means have a bath or clean using water and usually soap not the preparing for prayer. The other verb "read" also does not indicate or refer to reading Qura'an. The expression " كفى الله الثر (NM, p. 59) also is vague in meaning. It is translated as "what do you mean? That is too bad. (TLG, p.39)" the Arabic meaning is to ask for reasons or explanation about the status the one in however the English question may be asking for the meaning of what the speaker says. Another expression is " ان شاء اله (NM, p. 74) that may mean a lot in Arabic like intention or sarcasm or agreement to do something. The translation is "I hope so" which means only the meaning of hope. A lot of expressions are included in the "ترى بأي وجه يلقاك؟ " ecological cultural bound terms. One of them is (NM, P. 8) which means that Ilish cannot face or meet Said for betraying him, is translated in more general words as "how will he look when he first sees you? " (TLG, p. 10) the meaning here "seems". Another example is "يا كسوفي" (NM, P. 92) where the meaning may be happiness with shame. It is translated as "I'm sorry... (TLG, p.57)" which means apologizing. The material bound terms are represented in ".... (NM, p. 13) is translated as "sofas and chairs" which is more general in the Egyptian society and do not represent the cultural aspect of sofa or chair in the lower class.

Translation by a More Neutral/Less Expressive Word

This strategy has to do with differences in expressive meaning. The corpus contains (29) selected examples as follows:

Table (4): Translation by a More Neutral/Less Expressive Word

\begin{tabular}{|l|l|c|c|c|c|c|c|}
\hline No. & $\begin{array}{l}\text { Type of } \\
\text { strategy }\end{array}$ & HCBT & RCBT & ECBT & PSCBT & MCBT & $\begin{array}{c}\text { Total No. } \\
\text { examples }\end{array}$ \\
\hline 2 & $\begin{array}{l}\text { A more } \\
\text { neutral/less } \\
\text { expressive } \\
\text { word }\end{array}$ & 3 & 3 & 15 & 4 & 4 & 29 \\
\hline
\end{tabular}


On Translating Culture-Bound Expressions in Naguib Mahfouz's The Thief and the Dogs and strategies: A Comparative Study in Arabic-English Translation

Dr. Yousreya Ahmed Ali Alhamshary

مجلة وادي النيل للاراسات والبحوث الإنسانية والاجتماعية والتربوية (مجلة علمية محكمة)

\section{A more neutral/less expressive word}

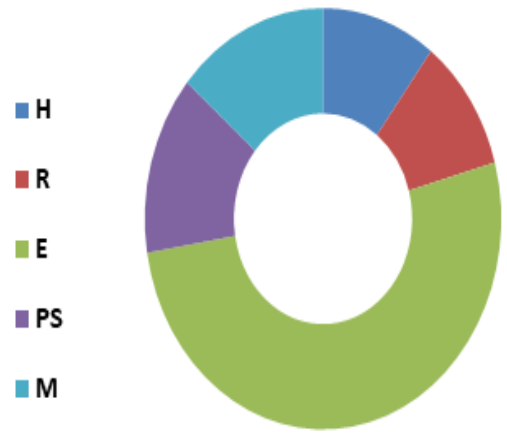

Figure (4): Translation by a More Neutral/Less Expressive Word

This strategy is employed mostly with ecological cultural bound terms may be due to the translator unaware of the social life of the lower class in Egypt. For example, the translator rendered the expression " .... تدرجت في النمو وهى صورة غامضا (NM, p. 8) as " where bit by bit she had taken shape, like an image in a dream, for long years... (TLG, p.9)". The appropriate meaning is that he did not watch her growing up so, he cannot decide here features or body shape. Another example is " .... سأخبر مدى حظى من لقياك" (NM, p. 9) where the translator used "when we meet, I'll know how I stand... (TLG, p.10)". The appropriate meaning is that he will be happy after a long time of not seeing Sanaa and the translator used the expression "how I stand" or the position Saeed will have from Sanaa's heat.

\section{Translation by Cultural Substitution}

This strategy involves replacing a cultural-specific expression or item with a target language expression or item which does not have the same propositional meaning but is likely to have a similar impact on the target reader (Baker, 1992, p. 31). The present study contains (24) selected items as follows: 
مجلة وادي النيل للاراسات والبحوث الإنسانية والاجتماعية والتربوية (مجلة علمية محكمة)

(ISSN : 2536 - 9555)

Table (5): Translation by Cultural Substitution

\begin{tabular}{|l|l|c|c|c|c|c|c|}
\hline No. & Type of strategy & HCBT & RCBT & ECBT & PSCBT & MCBT & $\begin{array}{l}\text { Total no. } \\
\text { examples }\end{array}$ \\
\hline 3 & $\begin{array}{l}\text { Cultural } \\
\text { Substitution }\end{array}$ & 3 & 2 & 13 & 2 & 4 & 24 \\
\hline
\end{tabular}

\section{Cultural Substitution}

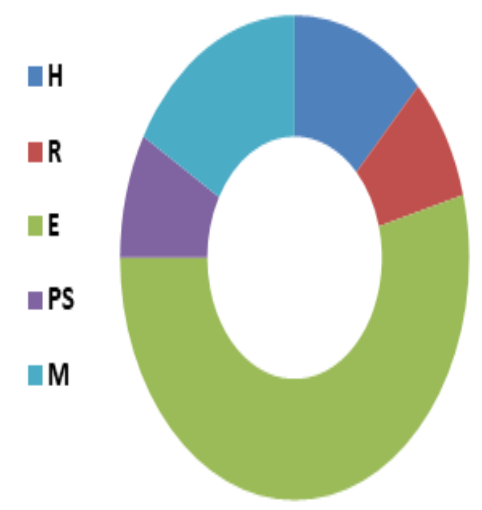

Figure (5): Translation by Cultural Substitution

All names of people and places are borrowed from the Egyptian society like Nabawiyya, Ilish Nur and Bayaza...etc. The culture aspect of the job "المخبر" (NM, p. 12) as a historical cultural sign is translated as "detective... (TLG, p.12)" which is not the same as in Egypt. Also, the utilization of "البخور" (NM, p. 22) as a material cultural sign is not the same. In Egypt is it used for religious divine Aspect, but in English it is used with witches and magic as in Egypt too. The expression " حزر فزر (NM, p. 26) is loaned from the English game "give toy three guesses ... (TLG, p.20)". The translator saw it necessary to use the strategy of cultural approximation because he knows very well that the literal translation "guess what" will have no sense in this context.

Translation Using a Loan Word or Loan Word Plus Explanation

The present study contains (19) selected items as follows: 
On Translating Culture-Bound Expressions in Naguib Mahfouz's The Thief and the Dogs and strategies: A Comparative Study in Arabic-English Translation

Dr. Yousreya Ahmed Ali Alhamshary

مجلة وادي النيل للاراسات والبحوث الإنساتية والاجتماعية والتربوية (مجلة علمية محكمة)

Table (6): Translation Using a Loan Word or Loan Word Plus Explanation

\begin{tabular}{|c|l|c|c|c|c|c|c|}
\hline No & Type of strategy & HCBT & RCBT & ECBT & PSCBT & MCBT & $\begin{array}{c}\text { Total no. } \\
\text { examples }\end{array}$ \\
\hline 4 & $\begin{array}{l}\text { a Loan Word or } \\
\text { Loan Word Plus } \\
\text { Explanation }\end{array}$ & 5 & 2 & 4 & 4 & 4 & 19 \\
\hline
\end{tabular}

1 a Loan Word or Loan Word Plus Explanation

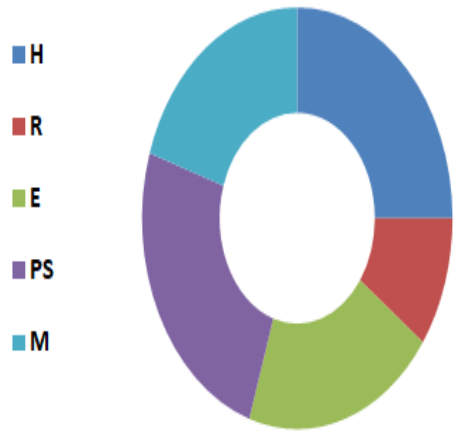

Figure (6): Translation Using a Loan Word or Loan Word Plus Explanation

The expression " عن ظهر قلب (NM, p. 52) rendered as a "like an open book... (TLG, p. 35)" and it can be "كويس اوي" which may be "quite well". The translator saw it necessary to use the strategy of cultural approximation because he knows very well that the literal translation "as a back heart" will have no sense in this context. The other expression " معلم القهوة وصبيه" (NM, p. 57) which is translated as "proprietor and his waiter... (TLG, p. 38)" where the translator used "Mr" for the expression "معلم" on other places in the story, the waiter in English is the not like "صبى القهوة" in Arabic as the later as a cultural sign of the Egyptian society can go home and buy things to the family too. The translator saw it necessary to use the strategy of cultural approximation because he knows very well that the literal translation "the child of the café " will have no sense in this context. The translator also loaned the expression "a solemn 
(ISSN : 2536 - 9555)

promise ... (TLG, p.46)" for the expression " ... وعد رجل (NM, p. 74 ) as the first is divine for the English people and the latter is greatly respected and considered as an oath to the Egyptian. The translator saw it necessary to use the strategy of cultural approximation because he knows very well that the literal translation" a man's oath" will have no sense in this context. This shows how important context is as far as meaning is concerned. It is also one of the reasons for the translator to consider the circumstances in which items uttered. The translator used the "يا خبر ابيض" expression "heaven ... (TLG, p. 71)" for the expression" (NM, p. 186) as he saw it necessary to use the strategy of cultural approximation because he knows very well that the literal translation of " oh white news" will make no sense in this place. The same is not for the expression "Sharia Muhammad Ali... (TLG, p.54)" to be translated as "Mohammed Ali street" as this street has a very famous reputation so the translator preferred to use "Sharia" to keep the historical meaning for the street. The expression "dead drunk" has nothing to do with the Arabic meaning " "لا يعرف راسه من رجليه (NM, p. 64) as the literal translation could not be "does not know his feet from head" which has no sense. The real meaning is unconscious or unaware to his surrounds.

\section{Translation by Paraphrase Using a Related Word}

This strategy is used "when the concept expressed by the source item is lexicalized in the TL but in different form, and when the frequency with which a certain form is used in the ST is significantly higher than would be natural in the TL" (Baker, 1992, p. 37). In other words, the meaning of the SL word is explained (Newmark, 1988, p. 91). It should be noted that this strategy is the most common way of translating color idioms when a match cannot be found in the TL or when it is inappropriate to use idiomatic language in the TT due to the differences in stylistic preferences of the SL and TL. By using this strategy, the impact of the idiom and its cultural significance will be lost (Baker, 1992, p. 74). The corpus contains (38) selected examples as follows: 
On Translating Culture-Bound Expressions in Naguib Mahfouz's The Thief and the Dogs and strategies: A Comparative Study in Arabic-English Translation

Dr. Yousreya Ahmed Ali Alhamshary

مجلة وادي النيل للاراسات والبحوث الإنسانية والاجتماعية والتربوية (مجلة علمية محكمة)

Table (7): Translation by Paraphrase Using a Related Word

\begin{tabular}{|l|l|l|l|l|l|l|c|}
\hline no & Type of strategy & HCBT & RCBT & ECBT & PSCBT & MCBT & $\begin{array}{c}\text { Total no. } \\
\text { examples }\end{array}$ \\
\hline 5 & $\begin{array}{l}\text { Paraphrase Using } \\
\text { a Related Word }\end{array}$ & 0 & 5 & 18 & 10 & 5 & 38 \\
\hline
\end{tabular}

\section{Paraphrase Using a Related Word}

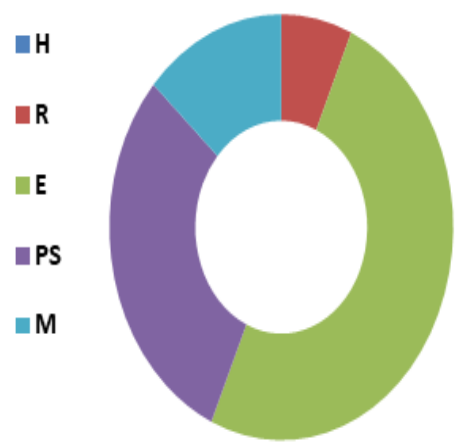

Figure (7): Translation by Paraphrase Using a Related Word

To illustrate further, consider the following example:

The psychological cultural sign " لا شفه تفتر عن ابتسامه" (NM, p. 8) is translated as "No one smile or seemed happy. But who of these people could have suffered more than he had? ... (TLG, p.9)". The translator can say easily "nobody smile" but he adds the sentence". But who of these people could have suffered more than he had?" to add more to the meaning in English. The expression " وسناء" (NM, p. 8) is not enough to the English reader so, the translator added what about Sanaa to illustrate that Seed is very worry about his daughter. He knows that "and Sanaa" will not be enough to express Said's worries. The expression " ... لم تغب عن باله" (NM, p. 8) can be easily rendered as "he never forget her", but the translator used "she had never been out of his thought... (TLG, p. 9)"

\section{Translation by Paraphrase Using Unrelated Word}

This strategy means that the translator uses a concept to express the source item which is not lexicalized at all in the target 
(ISSN : 2536 - 9555)

language contexts. Instead of a related word, the paraphrase may use other unrelated words to give the semantic meaning. The corpus contains (17) selected examples as follows:

Table (8): Translation by Paraphrase Using Unrelated Word

\begin{tabular}{|c|l|c|c|c|c|c|c|}
\hline No. & Type of strategy & HCBT & RCBT & ECBT & PSCBT & MCBT & $\begin{array}{c}\text { Total no. } \\
\text { examples }\end{array}$ \\
\hline 6 & $\begin{array}{l}\text { Paraphrase Using } \\
\text { Unrelated Word }\end{array}$ & 0 & 2 & 9 & 5 & 1 & 17 \\
\hline
\end{tabular}

\section{Paraphrase Using Unrelated Word}

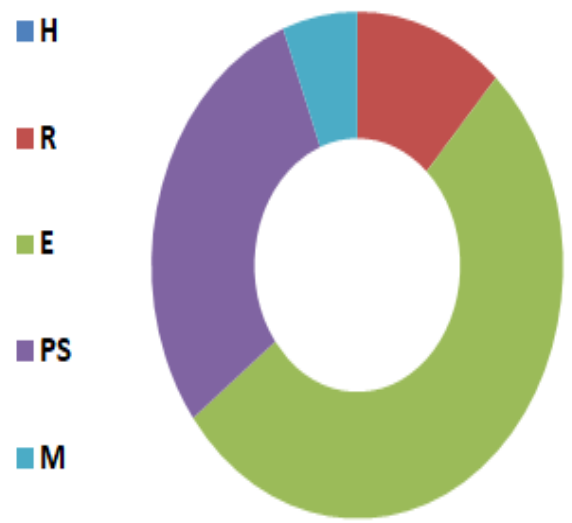

Figure (8): Translation by Paraphrase Using Unrelated Word

As an example, the expression " انتما تعملان لهذا اليوم الف حساب" (NM, p. 8) is translated as "for years you have been thinking about this day ... (TLG, p. 9)". The verb "think" has nothing to do with the verb "work" but the whole expression give the same meaning of the Arabic sentence. The same is about "تترقبان في حذر" (NM, p. 8) rendered as "watching now" which means in Arabic that they are looking at Said. But it gives the same meaning to the Arabic meaning of the expression. The expression "there is some business I have to settle (TLG, p.11)" has nothing to do with the expression "حساب أسويه"in Arabic. The expression " dead drunk" "لا يعرف راسه من رجليه " has nothing to do with the Arabic meaning " (NM, p. 64) as the translation could not be "does not know his feet 
On Translating Culture-Bound Expressions in Naguib Mahfouz's The Thief and the Dogs and strategies: A Comparative Study in Arabic-English Translation Dr. Yousreya Ahmed Ali Alhamshary

مجلة وادي النيل للاراسات والبحوث الإنسانية والاجتماعية والتربوية (مجلة علمية محكمة)

from head" which have no sense in the translation. The real meaning is unconscious or unaware to his surrounds. The head and feet have nothing to do with being aware but the whole expression render the real meaning of the context.

\section{Translation by Omission}

Throughout the novel, a lot of expressions derived from the social lower class are missed especially in the descriptive scenes where the smell of the Egyptian spirit can be smelled. The omission strategy is another one that translators can consider when there is no match in the target language or the meaning of an idiom cannot be paraphrased, or for stylistic reasons. Baker (1992, p. 40) points out that "this strategy may sound rather drastic, but it does not much harm to omit translating a word or expression in some contexts, especially if the meaning conveyed by a particular item or expression is not vital to the development of the text to justify distracting the reader with lengthy explanations, translators can and often do simply omit translating the word or expression in question". There are cases where omission is required to avoid redundancy and awkwardness (Nida, 1964, p. 228), and this strategy is particularly applied if the source language tends be a redundant language.

As Baker (1992, p. 40), states "deletion may also refer to pieces of content rather than restructuring for grammatical purposes". Such a deletion of expressions or information is debatable in relation to the translation of academic texts, however. Anyone who writes an academic text, for example, will not include unimportant information in his or her writing. Similarly, anyone who reads such a text should consider that all information in the text is important. Translators are not an exception; they should read the text as the original reader or a non-translator reader reads it. This notion of information deletion should not be used as "an excuse" to hide the inability of translators to understand and transfer message of the original text. The corpus contains (12) selected items as follows: 
(ISSN : 2536 - 9555)

Table (9): Translation by Omission

\begin{tabular}{|l|l|c|c|c|c|c|c|}
\hline No. & $\begin{array}{l}\text { Type of } \\
\text { strategy }\end{array}$ & HCBT & RCBT & ECBT & PSCBT & MCBT & $\begin{array}{l}\text { Total no. } \\
\text { examples }\end{array}$ \\
\hline 7 & Omission & 0 & 1 & 5 & 5 & 1 & 12 \\
\hline
\end{tabular}

\section{Omission}

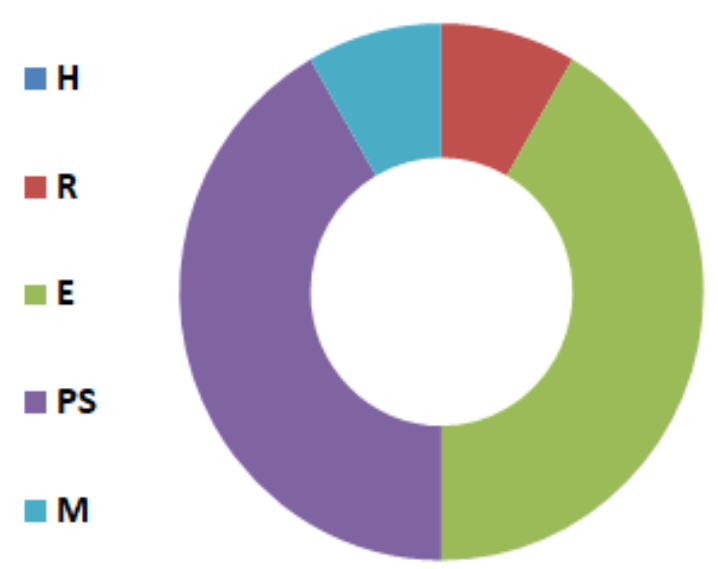

Figure (9): Translation by Omission

If the meaning conveyed by a particular item or expression is not vital enough to the development of the text to justify distracting the reader with lengthy explanations, translators can and often do simply omit translating the word or expression in question. In the present study, the translator omits some expressions although they can be expressed easily in English and add to the meaning like," ها "هي الدنيا تعود (NM, p. 7) that can be "life come back again", and " (NM, p. 8) that can be " homes and shops", and " وهو واحد خسر كتير... (NM, p. 8) "that can be "he is the one who lost a lot", or "طوال اربعة اعو ام خو (NM, p. 8) that can be "along four years". Other expressions are very difficult for not having any

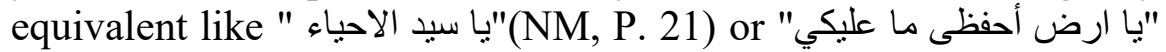
(NM, p. 57)," ليله بيضه بالصلاة علي النبي النصبة النحاسية " (NM, p. 57), (NM, p. 58), "خلو رجل (NM, p. 86). This omission restricted the meaning for the reader and does not give the right meaning.

From the previous discussion one can deduce that: 
On Translating Culture-Bound Expressions in Naguib Mahfouz's The Thief and the Dogs and strategies: A Comparative Study in Arabic-English Translation Dr. Yousreya Ahmed Ali Alhamshary

مجلة وادي النيل للاراسات والبحوث الإنسانية والاجتماعية والتربوية (مجلة علمية محكمة)

- There are some lexical or cultural differences in the translated version that may cause meaning to lose in the intended message in the selected novel.

- Based on the nature of the novel, the most frequented cultural bound terms are the ecological cultural bound terms.

- A lot of meanings are lost due to the omission of expressions that add to the meaning and classify the nature of Egyptian social and cultural life.

- The most frequented strategy is paraphrasing using related words which means that the translator does not know a lot about the Egyptian social cultural life although he has a native assistant to help in understanding what is difficult for him.

- The translation of these literary works needs revision from specialized Arabic scholars to explain the Arabic context and text.

- A similar revision may be executed to the other translations of Naguib Mahfouz's works as they are a very rich source for the Egyptian life at this time of writing.

\section{Conclusion}

As seen above cultural bound terms or cultural-specific terms are responsible for keeping the social and cultural identity of any society. The results of this research show that, according to Baker's (1992) theory the writer finds seven strategies out of eight translation strategies, there are translation by a more general word, translation by a more neutral/less expressive word, translation by cultural substitution, translation using a loan word or loan word plus explanation, translation by paraphrase using related word, translation by paraphrase using unrelated words, and translation by omission.

From (159) items, there are (23) items (14.4\%) belong to Translation by a more general word, (26) items (16.3\%) belong to Translation by a more neutral/less expressive word, (24) items (15\%) belong to Translation by cultural substitution, (19) items $(11.9 \%)$ belong to Translation using a loan word or loan word plus 
(ISSN : 2536 - 9555)

explanation, and (38) items (23.6\%) belong to Translation by paraphrase. From 159 items, there are (17) items (10.6\%) belong to Translation by paraphrase using unrelated words, (12) items (7.5\%) belong to Translation by omission. The percentages show that Translation using paraphrasing using related words is the most dominant. From the tables and the graphs, the ecological cultural bound terms are the most frequent cultural bound terms due to the nature of the novel and the context it deals with besides the social class it represents. The second frequent cultural bound terms are the psychological cultural ones which also represent the spiritual and status of the Egyptian character. Following this, are the material cultural bound terms that distinguish the Egyptian society and give the special taste for the social life. The least frequent cultural bound terms are the historical ones as the target of the novel is to represent the real social cultural life of this class, not to focus on the history of the period. Both translators of "The Thief and the Dogs" are sometimes aware of their cultural significance, especially when expressions refer to very popular ecological or cultural psychological bound terms. Therefore, they add explanatory information to make the message closer to their audience. However, these additions can be inadequate due to the cultural gap between the two languages.

Finally, translators' methods speak of their efforts to bring about a representative rendering of an Arabic novel. Egypt appears as a place where different civilizations have interacted throughout history. Due to the number of revised translated works of Mahfouz, it is believed that the analysis of The Thief and the Dogs could lead to shedding light in future studies on some other works which have been re-translated for certain reasons or to focus on social aspects that are missing in real current Egyptian life, whether revised by the same translator or by other translators. Further studies cab be conducted about the same story or other stories style of writing and translated text. Subtitling also can be revised to check how far does it convey the real meaning of the original text. Other translated works representing cultural side should be revised in terms of semantic and pragmatic meaning they reflect. 
On Translating Culture-Bound Expressions in Naguib Mahfouz's The Thief and the Dogs and strategies: A Comparative Study in Arabic-English Translation

Dr. Yousreya Ahmed Ali Alhamshary

مجلة وادي النيل للار اسات والبحوث الإنساتية والاجتماعية والتربوية (مجلة علمية محكمة)

\section{Appendix (1): Abbreviations:}

Historical cultural bound terms

Religious cultural bound terms

Ecological cultural bound terms

Psychological cultural bound terms

Material cultural bound terms

Naguib Mahfouz

Trevor Le Gassick

Source text

Target text
HCBT

RCBT

ECBT

PSCBT

MCBT

NM

TLG

ST

TT 
مجلة وادي النيل للاراسات والبحوث الإنسانية والاجتماعية والتربوية (مجلة علمية محكمة)

(ISSN : 2536 - 9555)

\section{References}

Abd Alhafez, A. (2003) Pragmatic and Linguistic Problems in the Translation of Naguib Mahfouz's The Thief and the Dogs: A Case Study. January 2003 Babel, 49, (3):229-252.

Abdul Wahab, A., and Ali, A. (2016) A Contrastive Analysis of English and Arabic Translation Problems. Humanities, The journal of Sudan University for Science and Technology, 17(4), 131-144.

Aixela, J. (1996). Culture-specific items in translation. In R. Alvarez \& M. Carmen-Africa Vidal (Eds.), Translation, power, subversion (pp. 52-78). Clevedon: Multilingual Maters.

Aldawood, S. (2017) Representing the Other in the Translation of Culture-Specific Elements in Literary Texts: Wolves of the Crescent Moon as a Case Study. International Journal of Language and Linguistics, 4, (2), 29-40.

Al Gamal, A., (2000) presupposition in the English translation of Naguib Mahfouz's Midaq Alley, Mirramar and Fountain and Tomp. An unpublished Dissertation. Faculty of languages (Alalsun).

Alkhawaja, L. (2014). The role of social agents in the translation into English of the novels of Naguib Mahfouz. 
On Translating Culture-Bound Expressions in Naguib Mahfouz's The Thief and the Dogs and strategies: A Comparative Study in Arabic-English Translation Dr. Yousreya Ahmed Ali Alhamshary

مجلة وادي النيل للاراسات والبحوث الإنسانية والاجتماعية والتربوية (مجلة علمية محكمة)

Unpublished PhD Thesis, Aston University, Birmingham, UK.

Allen, R. (1988) The Nineteen Eighty-Eight Nobel Prize in Literature Najib Mahfouz. In Dictionary of Literary Biography. Ed. J.M. Brook, Detroit, Michigan: Gale Research Inc.

Al-Saidi, A. (2013) Problems of Translating Cultural Bound terms with Reference to English and Arabic. Journal of University of ThiQar, 8(3).

Altoma, S. (2005). Modern Arabic Literature in Translation. London: Westbourne Grove.

Aziz, Y. (1993) Explicit and Implicit Reference in Arabic Translation. Babel, 39, (3), 129-150.

Baker, M. (1992). In Other Words: A Course book on Translation. $2^{\text {nd }}$ Ed. London: Routledge.

Baker, M. (2018). In Other Words: A Course book on Translation. $3^{\text {rd }}$ Ed. London: Routledge.

Bassnett, S. (1980). Translation Studies. London: Methuen \& Co. Ltd

Bassnett, S. (2002). Translation Studies. London; New York: Routledge. 
مجلة وادي النيل للار اسات والبحوث الإنسانية والاجتماعية والتربوية (مجلة علمية محكمة)

(ISSN : 2536 - 9555)

Bassnett, S., \& Lefevere, A. (1998). Constructing Cultures: Essays on Literary Translation. Clevedon: Multilingual Matters.

Bhabha, H. K. (1994). The Location of Culture. London: Routledge.

Blackburn, S. (1996). "Implicature," The Oxford Dictionary of Philosophy. Oxford: Publisher.

Braçaj, M. (2015). Procedures of Translating Culture-Specific Concepts, Mediterranean Journal of Social Sciences, 6(1), 467-480.

Catford, J (1965). A Linguistic Theory of Translation Oxford University. Press

Daoud, J. (2017). Equivalence Problems in Translation. Sino-US English Teaching, 14(2), 86-97.

Enani, M. (1997). [Fan Al-Tarjama] The Art of Translation. Cairo: The International Egyptian Company. Longman.

Farghal, M. \& Borinin, A. (1998). Pragma-linguistic Failure and the Translatability of Arabic Politeness Formulas into English: A Case Study of Mahfouz's Awlad Haritna " I Shunnaq et. Al. (eds.) Issues in Translation Jordan Irbid national University. Pp. 143-168.

Guessabi, F. (2013) The Cultural Problems in Translating a Novel from Arabic to English Language: A Case Study: the 
On Translating Culture-Bound Expressions in Naguib Mahfouz's The Thief and the Dogs and strategies: A Comparative Study in Arabic-English Translation Dr. Yousreya Ahmed Ali Alhamshary

مجلة وادي النيل للاراسات والبحوث الإنسانية والاجتماعية والتربوية (مجلة علمية محكمة)

Algerian Novel. Arab World English journal International Peer Reviewed Journal, 1(2), 224-232.

Hardwick, L. (2004). Translating words, Translating Cultures. Classical Inter/Faces. London, U.K.: Duckworth.

Haque, Z. (2012) Translating Literary Prose: Problems and Solutions. International Journal of English Linguistics, 2(6), 1923-869.

House, J. (1977) A Model for Translation Quality Assessment, Tübingen: Gunter Narr.

Khalil, S. \& Saad, I. (2017) A Discoursal Analysis of Grammatical Shift' in Najeeb Mahfouz's Novel 'The Thief and Dogs. Journal of Education College for Women. No. 20-11.

Kashgary, M. (2011). The Paradox of Translating the Untranslatable: Equivalence vs. Non-Equivalence in Translating from Arabic into English. Journal of King Saud University - Languages and Translation, 23, 47-57

Le Gassick, T. Badawi, M. (1984) Introduction. The Thief and the Dogs, Naguib Mahfouz, The American University Press.

Lefevere, A, (1994) Translating Literature, Practice and Theory in a Comparative Literature Context, Second Edition, the Modern Language Association of America. 
مجلة وادي النيل للاراسات والبحوث الإنسانية والاجتماعية والتربوية (مجلة علمية محكمة)

(ISSN : 2536 - 9555)

Liu, Z. (1991). Ten Lectures on Literary Translation. Beijing: China Translation and Publishing Corporation.

Mahfouz, N. (1975) [Midaqq Alley]. Trevor Le Gassick. Heinemann Educational Books Ltd.

Mohamed, T. (2014) Cohesion and Coherence Interrelation: An Approach to Literary Translation-Mahfouz's Trilogy. International Journal of Linguistics, 6(2),5549.

Muhaidat, F., \& Neimneh, S. (2011) Translators as Intercultural Mediators: Translating Religious Expressions in Naguib Mahfouz's Palace of Desire into English. Higher Education of Social Science, 1(1), 14-23.

Munday, J. (2012) Introducing Translation Studies, $3^{\text {rd }}$ d, London, and New York: Routledge.

Mussa, F. (1965) Bain Adabain Dirasat fi'l Adab Arab1 wa 'lEngllzi (Between Two Literatures: Studies in Arabic and English Literatures). Cairo: The Egyptian Anglo Bookstore, 1965.

Newmark, P. (1988). A Textbook of Translation. New York \& London: Prentice Hall.

Nida, E. (1964). Towards a science of translation, with special reference to principles and procedures involved in Bible translating. Leiden: Brill.

186 
On Translating Culture-Bound Expressions in Naguib Mahfouz's The Thief and the Dogs and strategies: A Comparative Study in Arabic-English Translation Dr. Yousreya Ahmed Ali Alhamshary

مجلة وادي النيل للاراسات والبحوث الإنسانية والاجتماعية والتربوية (مجلة علمية محكمة)

Nida, E. and Taber, C. (1982). The Theory and Practice of translation. Leiden: Brill.

Obeidat, H. (1998) Stylistic Aspects in Arabic and English Translated Literary Texts: A Contrastive Study. Translators' Journal, 43(3), 462-467.

Paz, O. (1971). Traduccion: literatura y literalidad. Barcelona:

Tusquets Editor.

Pym, A. (1992). Translation and Text Transfer: An Essay on the Principles of Intercultural Communication. Frankfurt am Main: P. Lang.

Salim, J. \& Mehawesh, M. (2013) Color Idiomatic Expressions in the Translation of Naguib Mahfouz's Novel "The Thief and the Dogs": A Case Study. International Journal of English Linguistics, 3(4), 107-190.

Salti, R. (1990) A Note on Mahfouz's Effort to Strike a Balance Between East and West. International Fiction Review, 17(2), 93-95.

Saule, B.\& Aisulu, N. (2014) Problems of translation theory and practice: Original and translated text equivalence, Procedia - Social and Behavioral Sciences, 136, 119-123.

Sutopo, A. (2001). Translation. Surakarta: Muhammadiyah University Press. 
(ISSN : 2536 - 9555)

Tresilian, D. (2008). A Brief Introduction to Modern Arabic Literature. London: Saqi.

Toury, G. (1995) Descriptive Translation Studies and Beyond, John Benjamins Publishing Company, Amsterdam.

Vinay, J. \& Darbelnet, J. (1995) Comparative Stylistics of French and English: A Methodology for Translation. Amsterdam and Philadelphia. John Benjamins Publishing Company.

Zhen, X. (2016) Translation Equivalence and the Reader's Response. International Review of Social Sciences and Humanities, 10(2), 98-109.

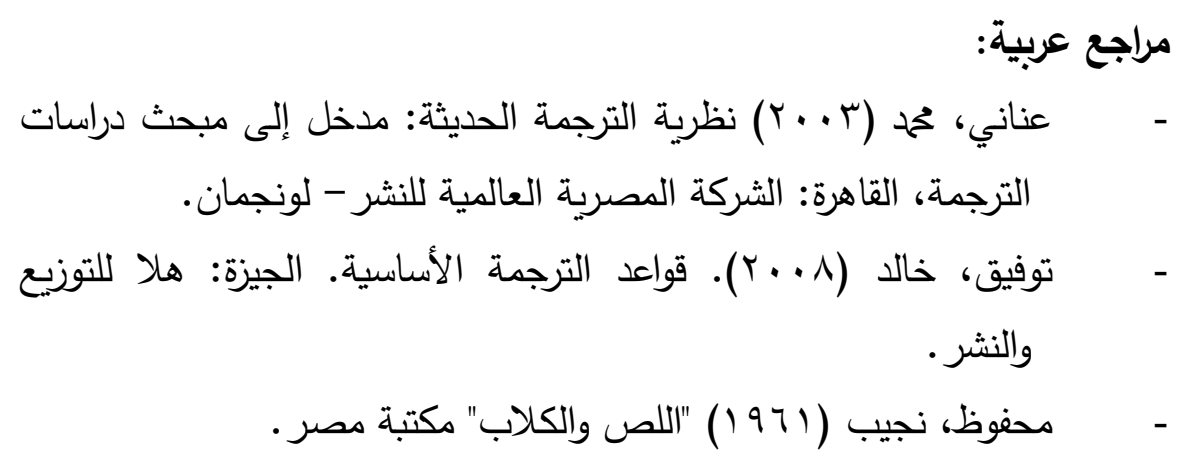

